\title{
DEKOMPOSISI AIR-METANOL MENJADI HIDROGEN PADA SEMIKONDUKTOR NATRIUM TANTALUM OKSIDA DENGAN MENGGUNAKAN LANTANUM SEBAGAI DOPING
}

\author{
Husni Husin ${ }^{1,2}$, Komala Pontas ${ }^{1,2}$, Hesti Meilina ${ }^{1,2}$, Fikri Hasfita ${ }^{3}$ \\ ${ }^{1}$ Program Magister Teknik Kimia, Program Pascasarjana, Universitas Syiah Kuala \\ ${ }^{2}$ Jurusan Teknik Kimia, Fakultas Teknik, Universitas Syiah Kuala \\ Gedung Teknik Kimia, Jalan Tgk. Syeh Abdurrauh No. 7, Darussalam Banda Aceh, 23111 Indonesia \\ ${ }^{3}$ Jurusan Teknik Kimia, Fakultas Teknik, Universitas Malikussaleh \\ Lhoekseumawe, Aceh Utara, 24300 Indonesia \\ Email: husni_husin2002@yahoo.com; husni_husin@che.unsyiah.ac.id
}

\begin{abstract}
Abstrak
Penelitian tentang sintesis fotokatalis semikonduktor natrium tantalum oksida yang didoping lantanum (La$\mathrm{NaTaO}_{3}$ ) serta uji kinerja terhadap dekomposisi air-metanol telah dilakukan. Penelitian ini bertujuan untuk melihat pengaruh metanol sebagai donor elektron dalam campuran reaksi terhadap aktifitas fotokatalik produksi hidrogen. Sampel semikonduktor dikarakterisasi dengan metode $x$-ray diffractometer (XRD) untuk mengetahui komposisinya. Dari hasil analisis XRD terindikasi bahwa komponen penyusun sampel adalah $\mathrm{NaTaO}_{3}$ dan $\mathrm{Ta}_{2} \mathrm{O}_{5}$. Uji kinerja dilakukan dengan menyinari air-metanol sebanyak $400 \mathrm{ml}$ dan $1 \mathrm{~g}$ fotokatalis dalam reaktor gelas pyrex selama 4 jam pada suhu $30{ }^{\circ} \mathrm{C}$. Larutan metanol ditambahkan ke dalam air sebanyak 5, 10, dan 15\% volume. Sebagai pembanding dalam reaksi ini juga digunakan air murni. Hasil penelitian menunjukkan bahwa laju fotokatalitik evolusi hidrogen dari air murni adalah 0.3 (mmol/g.jam). Laju generasi hidrogen meningkat secara signifikan ketika ditambahkan metanol 5\%, 10\%, dan 15\%, yaitu: 2,68, 4,79, dan 8,72 (mmol/g.jam),berturut-turut. Hal ini mengindikasikan peran metanol bertindak sebagai donor elektron dan mengkonsumsi photogenerated hole (+) dan / atau oksigen, sehingga mengurangi rekombinasi elektron-hole. Mekanisme reaksi pada partikel semikonduktor $\mathrm{NaTaO}_{3}$ juga dilaporkan.
\end{abstract}

Kata kunci: Fotokatalis, semikonduktor, $\mathrm{NaTaO}_{3}$, hidrogen, energi bersih.

\begin{abstract}
Synthesis of semiconductor photocatalysts lanthanum-doped sodium tantalum oxide ( $\mathrm{La}_{\text {-NaTaO}}$ ) and its performance on water-methanol decomposition has been carried out. This research aimed is to examine the effect of methanol as an electron donor in the reaction to photocatalytic of hydrogen production. The samples are characterized by $x$-ray diffractometer $(X R D)$ to determine its composition. The results indicate that the products are composed of $\mathrm{NaTaO}_{3}$ and $\mathrm{Ta}_{2} \mathrm{O}_{5}$. The reaction is conducted by irradiating of watermethanol of $400 \mathrm{ml}$ and $1 \mathrm{~g}$ of photocatalyst in Pyrex glass reactor for $4 \mathrm{~h}$ at a temperature of $30^{\circ} \mathrm{C}$. The methanol solution is poured into the reactor of 5, 10, and 15 vol.\%. For comparison, in this reaction is also used only pure water. The results depict that the rate of photocatalytic hydrogen evolution from pure water as much as 0.3 (mmol/ g.h). Hydrogen generation rate increased significantly when the methanol are added of 5\%, 10\%, and 15\%, ie. 2.68, 4.79 and $8.72,(\mathrm{mmol} / \mathrm{g} . \mathrm{h})$, respectively. This has been attributed to the effect of added methanol, which acts as sacrificial electron donor and consumes photogenerated holes and/or oxygen, thereby decreasing the rates of electron-hole recombination. Reaction mechanism in semiconductor particles of $\mathrm{NaTaO}_{3}$ is also reported.
\end{abstract}

Keywords: Photocatalyst, semiconductors, $\mathrm{NaTaO}_{3}$, hydrogen, clean energy.

\section{Pendahuluan}

Sumber energi konvensional seperti: batubara, minyak bumi, dan lain-lain yang berasal dari fosil terancam semakin habis $[4,11]$. Oleh karena itu, perlu dicari energi terbarukan sebagai pengganti sumber dari fosil. Hidrogen dipertimbangkan sebagai bahan bakar ideal untuk energi masa depan. Bahan bakar hidrogen dapat diproduksi dari sumber energi bersih dan terbarukan. Matahari dan angin adalah dua sumber utama energi terbarukan, dan menjanjikan untuk produksi hidrogen [2]. Akan tetapi, dewasa ini, energi terbarukan hanya sekitar 5\% yang diproduksi secara komersial melalui elektrolisis air, selain itu, 95\% hidrogen diproduksi dari turunan bahan bakar fosil [9].

Produksi hidrogen dari sumber bahan terbarukan belum populer karena biaya produksi masih tinggi. Elektrolisis air fotovoltaik dapat menjadi lebih kompetitif karena biaya cenderung menurun seiring dengan kemajuan teknologi. Akan tetapi, proses produksi hidrogen dengan cara elektrolis air masih terlalu mahal. Sebagai 
penggantinya, proses water-splitting menggunakan semikonduktor menawarkan cara yang menjanjikan untuk produksi hidrogen bersih, murah, dan ramah lingkungan, serta menggunkan energi surya [3].

Sodium tantalum oksida yang diberi doping lantanum $\left(\mathrm{La}-\mathrm{NaTaO}_{3}\right)$ dianggap sebagai fotokatalis yang baik untuk memproduksi hidrogen karena aktivitasnya yang tinggi terhadap kedua cahaya dan larutan cair seperti air-metanol. Hidrogen memiliki potensi sebagai bahan bakar bersih, dapat diekstraksi dari sumber air, biomassa, gas alam dan karbon lainnya [8]. Alkohol dilaporkan sebagai sumber yang paling dipertimbangkan untuk bahan bakar hidrogen diantara energi bahan bakar cair lainnya [10]. Alkohol dapat dikonversi menjadi hidrogen melalui beberapa reaksi, termasuk ethanol dan methanol steam reforming [11], oksidasi parsial metanol [10], oksidatif reforming metanol, dekomposisis metanol [14] dan fotokatalitik pada semikonduktor [12]. Fotokatalitik dekomposisi alkohol menjadi hidrogen tampaknya merupakan metode yang sangat menjanjikan untuk teknologi praktis dan murah dalam sistem energi berbasis hidrogen [12]. Namun demikian, penyelidikan yang dilakukan beberapa tahun terakhir ini merekomendasikan penggunaan sumber campuran alkohol-air untuk produksi hidrogen. Proses ini dilangsungkan secara fotokatalitik pada kondisi suhu kamar menggunakan semikonduktor dan cahaya [13].

Tulisan ini melaporkan proses preparasi semikonduktor $\mathrm{NaTaO}_{3}$ yang didoping lantanum dan kinerjanya terhadap produksi hidrogen. Pengaruh penggunaan konsentrasi metanol serta mekanisme reaksi pada $\mathrm{NaTaO}_{3}$ juga dilaporkan.

\section{Teori}

Hidrogen dari air dewasa ini diproduksi secara elektrolisis dan fotokatalitik dekomposisi air. Pada elektrolisis air, penguraian molekul air $\left(\mathrm{H}_{2} \mathrm{O}\right)$ menjadi hidrogen $\left(\mathrm{H}_{2}\right)$ dan oksigen $\left(\mathrm{O}_{2}\right)$ menggunakan energi pemicu reaksi berupa energi listrik. Proses ini berlangsung ketika dua buah elektroda ditempatkan dalam air dan arus searah dilewatkan diantara 2 elektroda tersebut. Hidrogen terbentuk pada katoda, sementara oksigen pada anoda [7]. Elektrolisis dikenal sebagai produksi hidrogen dari air yang paling efektif dengan tingkat kemurnian tinggi.

Dekomposisi air menjadi $\mathrm{H}_{2}$ dan $\mathrm{O}_{2}$ secara fotokatalitik menggunakan fotokatalis semikonduktor adalah suatu metode konversi energi solar menjadi energi kimia, termasuk konversi biomassa dan elektrolisis air menggunakan solar cell [6]. Proses ini juga hampir sama dengan elektolisis air. Proses produksi hidrogen secara fotokatalitik menggunakan fotokatalis semikonduktor dan cahaya sebagai sumber photogenerated electron (-) dan hole (+). Proses ini pertama sekali diinisiasi oleh Honda dan Fujishima (1972), yang mendemonstrasikan reaksi pemisahan air pada rangkaian sel elektrokimia (photoelectrochemical (PEC) cell) menggunakan semikonduktor $\mathrm{TiO}_{2}$ sebagai anoda dan $\mathrm{Pt}$ (platinum) sebagai katoda [1]. Sel elektrokimia dibangun untuk mendekomposisi air menjadi hidrogen dan oksigen. Ketika permukaan semikonduktor $\mathrm{TiO}_{2}$ menyerap cahaya, maka elektron yang diserap semikonduktor mengalir dari anoda ke konter elektroda yang terbuat dari Pt melalui sirkuit eksternal. Oksigen diproduksi pada elektroda semikonduktor $\mathrm{TiO}_{2}$, sementara hidrogen dihasilkan pada elektroda Pt yang disebut dengan reaksi reduksi.

\section{Metodologi Penelitian}

\section{Bahan-bahan yang digunakan.}

Penelitian ini menggunakan bahan-bahan utama sebagai berikut: tantalum klorida, sodium hidroksida, asam sitrat anhydrous, etanol, larutan ammonia, metanol, air suling, gas argon, dan gas helium.

\section{Preparasi Katalis.}

Preparasi semikonduktor $\mathrm{NaTaO}_{3}$ dilakukan di Laboratorium Jurusan Teknik Kimia Universitas Syiah Kuala. Sampel $\mathrm{NaTaO}_{3}$ yang didoping dengan lantanum disiapkan seperti dilaporkan sebelumnya [4] dengan metode sol-gel menggunakan larutan etanol sebagai pelarut. Sintesis dilakukan dengan cara berikut ini: Semua senyawa yang diperlukan dilarutkan terlebih dahulu dalam solven. Senyawa $\mathrm{NaOH}$ dilarutkan dalam air suling. Sementra $\mathrm{TaCl}_{5}$ dilarutkan dalam etanol. Senyawa $\mathrm{La}\left(\mathrm{NO}_{3}\right)_{2} \cdot 2 \mathrm{H}_{2} \mathrm{O}$ dimasukkan ke dalam beaker glass sebanyak $2 \%$ mol dan dilarutkan dalam air suling. Semua campuran disatukan sambil diaduk terus-menerus. Selanjutnya asam sitrat disiapkan dalam $50 \mathrm{ml}$ air suling untuk diteteskan perlahan-lahan ke dalam larutan di atas. $\mathrm{Ke}$ dalam larutan tersebut ditambahkan larutan $\mathrm{NH}_{4} \mathrm{OH}$ sampai $\mathrm{pH}$ mencapai nilai 4. Proses pembentukan gel dilakukan dengan memanaskan larutan pada temperatur konstan $80{ }^{\circ} \mathrm{C}$ sampai terbentuk gel putih. Kemudian gel dikeringkan dalam oven pada suhu $120{ }^{\circ} \mathrm{C}$ selama lebih kurang 5 jam, selanjutnya dilakukan sintering pada suhu $400{ }^{\circ} \mathrm{C}$ dan dilanjutkan dengan kalsinasi pada suhu $800{ }^{\circ} \mathrm{C}$. Semikonduktor dianalisis dengan X-ray diffractometer (XRD).

\section{Uji Kinerja Katalis.}

Reaksi fotokatalitik dilakukan dalam reaktor gelas pyrex seperti yang dilaporkan sebelumnya [4]. Larutan air-metanol sebanyak $400 \mathrm{ml}$ dimasukkan ke dalam reaktor. Larutan metanol divariasikan yaitu: $5 \%, 10 \%$, dan $15 \%$ volume. Selanjutnya semikonduktor $\mathrm{NaTaO}_{3}$ yang didoping dengan lantanum sebanyak $1 \mathrm{~g}$ dimasukkan ke dalam larutan tersebut. Campuran diaduk terus-menerus menggunakan magnetic stirrer. Untuk menghilangkan udara, reaktor dialirkan gas Argon 
lebih kurang setengah jam. Campuran reaksi disinari dengan sinar ultra violet (UV) untuk menyerap elektron dan proton oleh semikonduktor. Sumber radiasi menggunakan lampu merkuri $450 \mathrm{~W}$ bertekanan sedang. Gas hasil di alirkan ke kolektor gas untuk menetukan volume $\mathrm{H}_{2}$.

\section{Hasil}

1. X-ray difraktometer (XRD) $\mathrm{La}^{-\mathrm{NaTaO}_{3}}$ hasil analisis dan standard $\mathrm{NaTaO}_{3}$.

Karakterisasi fotokatalis dengan XRD bertujuan untuk mengidentifikasi komponenkomponen penyusun fotokatalis. Analisis ini dilakukan di laboratorium XRD Jurusan Fisika Universitas Syiah Kuala Banda Aceh. Gambar 1 dan 2 menampilkan diffractogram semikonduktor La$\mathrm{NaTaO}_{3}$ dan standard $\mathrm{NaTaO}_{3}$. Lantanum ditambahkan sebagai doping untuk meningkatkan kristalinitas sampel $\mathrm{NaTaO}_{3}$.

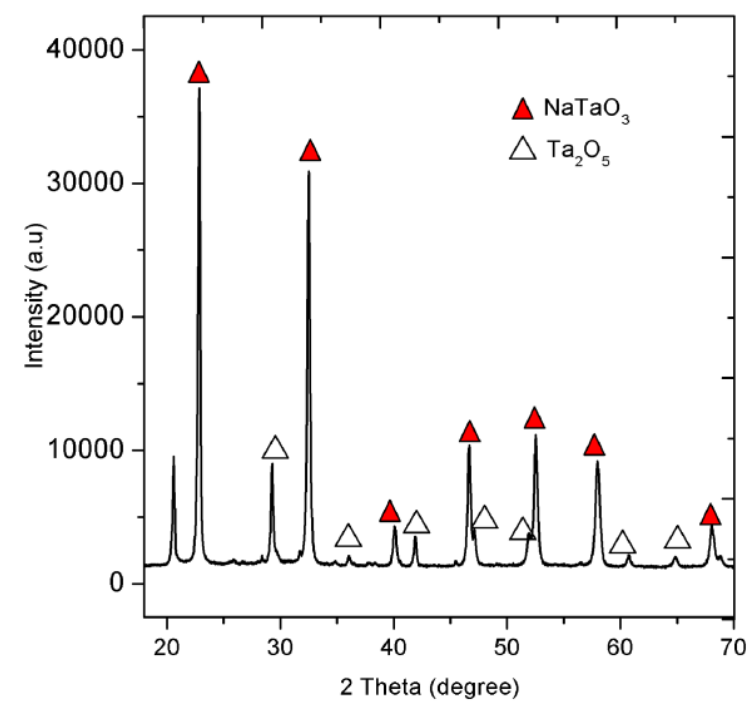

Gambar 1. Spektrum XRD sampel semikonduktor $\mathrm{NaTaO}_{3}$ didoping lantanum

Pembacaan data XRD sampel dilakukan dengan cara membandingkan spektrum XRD fotokatalis sintesis dengan spektrum senyawa standard powder data file JCPDS (Joint Committee Powder Diffraction Standard) sesuai nomor katalog komponen penyusun [5]. Dari hasil karakterisasi XRD sampel (seperti diperlihatkan pada Gambar 1), dan dilakukan konfirmasi perbandingan dengan XRD standard $\mathrm{NaTaO}_{3}$ (lihat Gambar 2) mengilustrasikan bahwa tiga puncak utama karakteristik $\mathrm{NaTaO}_{3}$ terindikasi pada $2 \theta 22,9^{\circ} ; 32,6^{\circ}$; dan $52,7^{\circ}$; sesuai dengan JCPDF No. 25-0863. Puncak-puncak lainnya juga merupakan pola difraksi $\mathrm{NaTaO}_{3}$ dengan intensitas yang lebih rendah. Dari spektrum XRD sampel tidak terlihat adanya puncak-puncak karakteristik senyawa lantanum. Hal ini kemungkinan karena konsentrasi lantanum dalam sampel sangat kecil yaitu hanya $2 \%$.
Akan tetapi, dari spektrum XRD sampel (Gambar 1) juga terdeteksi adanya senyawa $\mathrm{Ta}_{2} \mathrm{O}_{5}$ yang terbentuk dari sampel dengan intensitas yang rendah. Hasil ini teridentifikasi setelah dibandingkan dengan spectrum XRD senyawa standard $\mathrm{Ta}_{2} \mathrm{O}_{5}$, sesuai dengan JCPDF No. 33-3391.

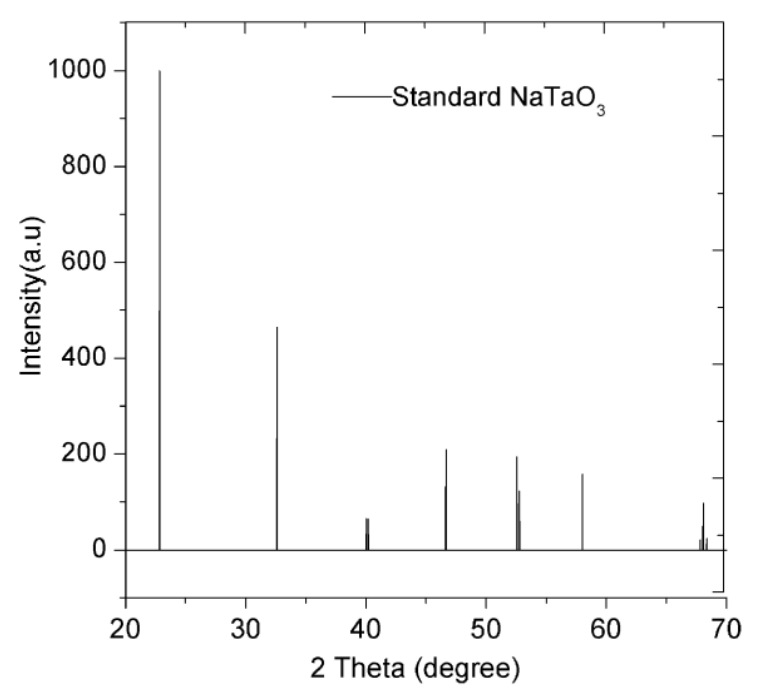

Gambar 2. Spektrum XRD senyawa standard $\mathrm{NaTaO}_{3}$

Fenomena terbentuknya $\mathrm{Ta}_{2} \mathrm{O}_{5}$ diyakini karena proses chelating menggunakan asam sitrat belum dapat mengikat semua kation-kation dan anion pembentuk La- $\mathrm{NaTaO}_{3}$ dengan sempurna, sehingga sebagian kation tantalum dan oksigen membentuk oksida $\mathrm{Ta}_{2} \mathrm{O}_{5}$. Senyawa tantalum oksida $\left(\mathrm{Ta}_{2} \mathrm{O}_{5}\right)$ juga dapat mempercepat terjadinya reaksi pembentukan hidrogen dari larutan air-metanol.

\section{Produksi hidrogen.}

Aktivitas fotokatalitik pada berbagai konsentrasi metanol ditentukan terhadap evolusi $\mathrm{H}_{2}$ dari suspensi semikonduktor dalam larutan airmetanol selama 4 jam dengan disinari sumber cahaya ultra violet. Seperti yang didemonstrasikan pada Gambar 3, jumlah laju evolusi $\mathrm{H}_{2}$ meningkat dengan meningkatnya kadar metanol dalam larutan. Ativitas fotokatalitik evolusi hidrogen dari air murni (tanpa metanol) terlihat rendah yaitu: 0,3 (mmol/g.jam). Perlu dicatat bahwa ketika metanol ditambahkan sebanyak $5 \%$ ke dalam larutan, laju evolusi $\mathrm{H}_{2}$ meningkat menjadi 2,.68 (mmol/g.jam). Hasil ini mengindikasikan bahwa walaupun penambahan metanol dalam jumlah kecil, aktifitas fotokatalitik meningkat karena peran metanol bereaksi dengan hole $(+)$ pada valence band membentuk ion $\mathrm{H}^{+}$yang selanjutnya bereaksi dengan electron (-) pada conduction band membentuk hidrogen. Fakta ini sejalan dengan penelitian yang dilaporkan oleh Miwa, dkk., 2007, yang melangsungkan reaksi fotokatalitik produksi hidrogen pada semikonduktor $\mathrm{TiO}_{2}$ dipadu dengan $\mathrm{CuO}$ sebagai ko-katalis [8]. 
Lebih lanjut, ketika larutan metanol ditambah mencapai $10 \%$ dan $15 \%$, laju evolusi hidrogen meningkat secara signifikan menjadi 4,79 dan 8.72 (mmol/g.jam) berturut-turut.

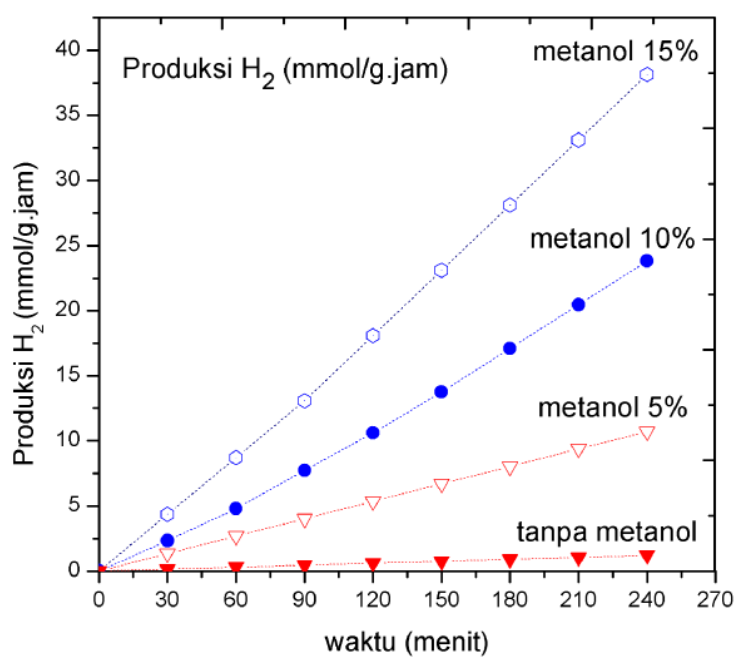

Gambar 3. Produksi $\mathrm{H}_{2}$ pada semikonduktor $\mathrm{NaTaO}_{3}$ didoping lantanum (serbuk $\mathrm{La}^{-\mathrm{NaTaO}_{3}} \mathrm{I} \mathrm{g}$ disuspensi ke dalam larutan air-metanol sebanyak $400 \mathrm{ml}$, konsentrasi metanol: $5 \%, 10 \%$, dan $15 \%$ )

Fakta ini mengisyaratkan bahwa makin tinggi konsentrasi maka metanol yang teradsorbsi pada permukaan semikonduktor semakin banyak membentuk spesies reaktif (radikal $\bullet \mathrm{OH}$ ). Metanol dalam larutan tidak ditambahkan lebih lanjut karena diharapkan dalam reaksi ini metanol digunakan sekecil mungkin, sementara air merupakan reaktan utama. Sreethawong dan Yoshikawa (2005), melaporkan bahwa kontribusi metanol dalam reaksi ini bertindak sebagai sacrificial electron donor dan mengkonsumsi photogenerated holes dan/atau oksigen, sehingga mengurangi laju rekombinasi electron-hole serta reaksi balik antara $\mathrm{H}_{2}$ dan $\mathrm{O}_{2}$ [12]. Laju generasi hidrogen tampak stabil hingga reaksi dihentikan sampai 4 jam.

\section{Mekanisme Reaksi.}

Untuk mendapatkan pengetahuan lebih lanjut tentang fotokatalitik proses evolusi hidrogen dari larutan air-matanol, berikut dijelaskan proses berlangsungnya dekomposisi air-metanol pada sebuah semikonduktor. Diagram alir mekanisme reaksi dekomposisi air-metanol pada semikonduktor diilustrasikan dalam Gambar 4.

Setiap semikonduktor memiliki valence band $(V B)$ atau pita valensi dan conduction band $(C B)$ atau pita konduksi. Pada tahap pertama semikonduktor menyerap cahaya yang mengandung photogenerated electron (-) dan hole (+). Energi yang dimiliki cahaya harus lebih besar dari energi band gab semikonduktor $\mathrm{NaTaO}_{3}$. Elektron pada valence band dieksitasi ke conduction band. Metanol dan air bertindak sebagai sacrificial reagent atau desebut electron donor, dimana bereaksi dengan hole pada valence band menghasilkan hidroksil $(\bullet \mathrm{OH})$, ion $\mathrm{H}^{+}$ dan HCHO. Ion $\mathrm{H}^{+}$selanjunya direduksi oleh electron pada conduction band untuk meregenerasi molekul hidrogen. Senyawa HCHO bereaksi dengan hole memproduksi $\mathrm{HCOOH}$, selanjutntnya terdekomposisi menjadi $\mathrm{CO}_{2}$ pada valence band.

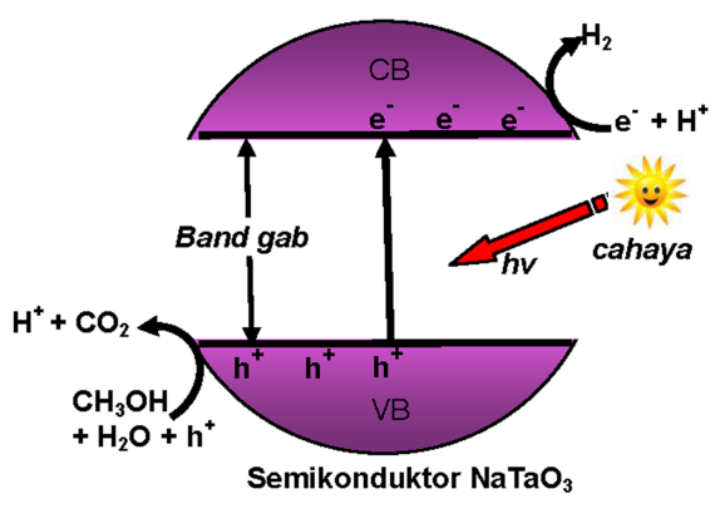

Gambar 4. Mekanisme reaksi dekomposisi air-metanol pada semikonduktor $\mathrm{NaTaO}_{3}$

Mekanisme yang ditampilkan pada Gambar 4 sesuai dengan hasil aktivitas fotokatalitik reaksi evolusi hidrogen yang terjadi pada fotokatalis semikonduktor $\mathrm{La}_{-} \mathrm{NaTaO}_{3}$, seperti yang didemonstrasikan pada Gambar 3. Ketika metanol ditambahkan ke dalam campuran reaksi, evolusi hidrogen meningkat secara signifikan karena hole bereaksi dengan metanol.

\section{Kesimpulan}

Penelitian ini mensintesis dan menggunakan fotokatalis $\mathrm{NaTaO}_{3}$ yang didoping dengan ion lantanum dan mengevaluasi kinerjanya pada 3 konsentrasi metanol sebagai donor elektron. Dari hasil percobaan dapat disimpulkan beberapa hal yaitu: (1) Fotokatalis yang dihasilkan menunjukkan terbentuknya senyawa $\mathrm{NaTaO}_{3}$ dan $\mathrm{Ta}_{2} \mathrm{O}_{5}$ yang dikonfirmasi dari spektrum XRD. (2) Jumlah evolusi hidrogen sangat dipengaruhi oleh kandungan metanol dalam larutan. (3) Semikonduktor $\mathrm{NaTaO}_{3}$ yang didoping ion $\mathrm{La}$ sangat cocok digunakan sebagai fotokatalis pada reaksi dekomposisi air-metanol menjadi hidrogen sebagai kandidat energi bersih masa depan.

\section{Ucapan Terimakasih}

Penulis mengucapkan terima kasih kepada Kementerian Nasional Republik Indonesia atas bantuan dana melalui Hibah Pascasarjana tahun 2013 dan kepada saudara Saisa, Syawal, dan Yulia Hayati atas bantuannya dalam pelaksanaan penelitian ini. 


\section{Daftar Pustaka}

[1] Fujishima, A, Honda K., Electrochemical photolysis of water at a semiconductor electrode. Nature 238 (1972) 37.

[2] Huang C, Yao W, Raissi A.T, Muradov N., Development of efficient photoreactors for solar hydrogen production. Solar Energy, 85 (2011) 19-27.

[3] Husin, H., Produksi Hidrogen Secara Fotokalitik dari Air Murni Pada Katalis $\mathrm{NaTaO}_{3}$. Jurnal Rekayasa Kimia dan Lingkungan, 9 (2012) 53-58.

[4] Husin, H., Fotokatalitik Dekomposisi Air menjadi hidrogen sebagai energi bersih dan ramah lingkungan. Rona Lingkungan Hidup, 6 (2013) 13-21.

[5] Husin, H., Zuhra, Hasfita F., Oksidasi parsial metana menjadi methanol dan formaldehida menggunakan katalis $\mathrm{CuMoO}_{3} / \mathrm{SiO}_{2}$ : Pengaruh rasio $\mathrm{Cu}$ : Mo, temperatur reaksi dan waktu tinggal, Jurnal Rekayasa Kimia \& Lingkungan, 6 (2007) 21-27.

[6] Kudo A., Recent progress in the development of visible light-driven powdered photocatalysts for water splitting. International Journal of Hydrogen Energy, 32 (2007) 26732678.

[7] Mazloomi K, Sulaiman N, Moayedi H., Electrical Efficiency of Electrolytic, Hydrogen Production. Int. J. Electrochem. Sci., 7 (2012) 3314-3326.

[8] Miwa T, Kaneco S, Katsumata H, Suzuki T, Ohta K, Chand Verma S, Sugihara K., Photocatalytic hydrogen production from aqueous methanol solution with $\mathrm{CuO} / \mathrm{Al}_{2} \mathrm{O}_{3} / \mathrm{TiO}_{2} \quad$ nanocomposite. International Journal of Hydrogen Energy, 35 (2010) 6554-6560.

[9] Ni M, Leung MKH, Leung DYC, Sumathy K., A review and recent developments in photocatalytic water-splitting using $\mathrm{TiO}_{2}$ for hydrogen production. Renewable and Sustainable Energy Reviews, 11 (2007) 401425.

[10] Ou TC, F.W.Chang, L.S.Roselin, Production of hydrogen via partial oxidation of methanol over bimetallic AueCu/TiO ${ }_{2}$ catalysts. Journal of Molecular Catalysis A: Chemical, 293 (2008) 8-16.

[11] Shishido T, Yamamoto Y, Morioka H, Takehira K., Production of hydrogen from methanol over $\mathrm{Cu} / \mathrm{ZnO}$ and $\mathrm{Cu} / \mathrm{ZnO} / \mathrm{Al}_{2} \mathrm{O}_{3}$ catalysts prepared by homogeneous precipitation: steam reforming and oxidative steam reforming. Journal of Molecular Catalysis A: Chemical, 268 (2007) 185-194.
[12] Sreethawong T, Yoshikawa S., Comparative investigation on photocatalytic hydrogen evolution over $\mathrm{Cu}-$, Pd-, and Au-loaded mesoporous $\mathrm{TiO}_{2}$ photocatalysts. Catalysis Communications, 6 (2005) 661-668.

[13] Strataki N, Bekiari V, Dimitris I, Kondarides, Lianos P., Hydrogen production by photocatalytic alcohol reforming employing highly efficient nanocrystalline titania films. Applied Catalysis B: Environmental, 77(2007)184-189.

[14] Wu GS, Wang L.C, Liu Y.M, Cao Y, Dai W. L, He H.Y., Implication of the role of oxygen anions and oxygen vacancies for methanol decomposition over zirconia supported copper catalysts. Applied Surface Science, 253(2006) 974-982. 